\title{
Setting Planning Standards for Public Facilities in a City: A Case Study of Ward 50 of Dhaka City Corporation
}

\author{
Mohammad Atikul Islam*
}

\begin{abstract}
Availability of different types of public facilities within an urban area is required to achieve specific objectives in urban planning. Planning standards are necessary in such cases to help achieve the adequacy and quality in services and facilities. To improve the situation in rapid and unplanned growth of Dhaka city both in terms of population and size, it demands a large amount of public facilities such as open spaces, playgrounds, schools, hospitals etc. School is an important public facility that requires setting standards and choosing appropriate locations. Standard of school facilities in an area depends upon factors such as, density of population, number of per family school going children, road network etc. This paper explores the existing facilities of primary and secondary schools for school going children in Ward 50 of Dhaka City Corporation. A series of field survey were conducted in order to collect information from primary sources, and standards on school facilities were collected from secondary sources. Based on the findings, suggestions on future planning of school facilities have been made in this paper. Finally, to justify the standards for schools facilities, DMDP planning standards are followed.
\end{abstract}

\section{Introduction}

Dhaka is a city of 400 years, which has grown beyond all expectations in terms of population and area. Dhaka was declared a Municipality by the British rulers in 1864. The first plan for Dhaka was made in 1917 by Patrick Geddes, the British Town Planner, with the concept of a Garden City. Master Plan of Dhaka was first prepared in 1959 and the Dhaka Metropolitan Development Plan (DMDP) was approved in 1997. Dhaka city has experienced a sharp rise in population through migration and the present estimated population of Dhaka is 13 million and estimated growth rate is $4.7 \%$ per annum (BBS, 2004).

Rapid and unplanned growth of Dhaka city both in terms of population and size, demands a large amount of public facilities such as open spaces, playgrounds, schools and hospitals. It is now recognized that making such provisions is a matter of public responsibility and these have to be implemented through the public facility planning.

Education plays an important role in our society. United Nations' Educational, Scientific, and Cultural Organization indicate that the development of education is advanced to the development of economy all over the world. World Bank points out that the Gross Domestic Product (GDP) of a country will increase 3\% with every one more year of education to a labourer (Yi, 2004). Education is said to be the backbone of a nation. The fundamental objective of education is to foster the sense of dignity, morality and social responsibility of individuals leading to the fulfillment of socioeconomic aspiration of a nation. Education should get the topmost priority to make it accessible to all. Furthermore, education is an effective way to eliminate poverty and to prosper the economy and society. In urban environment, school planning is a type of facilities planning that distributes schools realizing the practical importance of school location in urban area is based on the needs of the residents.

\section{Conceptual Framework}

The term planning standard is used to fix the minimum area for each use in the plan. These minimum standards are fixed for a particular locality by studying the functional requirement, 
number of users, open spaces required for the building, social and climatic condition, and economic activities of the locality. Murtaza (2009) observes that planning standards are based on the total amount of land required for selected urban services and facilities expressed in acres/hectres per threshold population in urban local bodies, such as Pourashava. It seeks to operationalize the development goal, which is primarily aimed at improving the quality of life of the people. An objective standard is likely to be a close approximation to human welfare and should, therefore, depend on local norms and other detailed aspects of the specific context. Rangwala (1996) mentioned that the planning standards should be carefully watched by the planning or enforcing authority and they may be reviewed and revised to meet the changing conditions. Thus the enforcing authorities of the planning standards and regulations play a significant role in achieving the desired goal in town planning.

Planning standards can be developed in overall proportions applying specific provisions and standard methods. Initially, most of the master plans prepared in Bangladesh, followed specific provision standards to suggest planning standards, for example, the first master plan of Dhaka (1959), Khulna (1961), and Rajshahi (1984). In these plans, they suggested for typical neighborhood unit of 100 acres (50 acres to be allowed for dwellings and 50 for ancillary services), accommodating 7500 persons. But the latest plan for Dhaka, DMDP (1995) ignored the standard size of neighborhood unit. Again, in 1985, the Urban Development Directorate (UDD) under the Ministry of Public Works undertook an initiative to prepare master/land use plans for all the Upazila and Zila Shahars (towns). They specified methods for both overall proportions and specific provisions to fix the planning standards.

\section{Objectives and Methodology}

The study has been selected to accomplish the objectives of identifying the total number and existing location of primary and secondary schools in Ward number 50 of Dhaka City Corporation and their capacity, determine the availability of schools in the study area based on the threshold populations for the planning standards and at the same time explore the inconveniences faced by the residents to access the schools (social cause will not take in consideration) and nature of school going children.

To achieve the objectives of this paper, a series of survey were conducted in order to collect information from primary sources. Standards of school facilities are collected from secondary sources. About 5\% households of the study area were selected for questionnaire survey. In case of reconnaissance and schools $100 \%$ coverage were taken. Finally, this paper prescribed requirements of school according to present planning standards compared with its real scenario in study area along with nature of school going students and schools.

\section{Community and Public Facility}

The central function of service facilities is to provide services to their users. Therefore, community service can be defined as those facilities which provide services to the members of a community, who live in a geographically congruous area and share the major portion of daily transactions of sustain needs. These facilities can be either in the private sector, the public sector or part of a joint public-private organization (ASCE, 1986).

The public facility is defined as the facility to which people must travel to receive the service, or from which a service is provided to the whole community of interest in administration, economy, education, health, scientific research and physical training. They provide important goods and services which contribute to and enhance the quality of life (Massam, 1993). They include schools, libraries, stadiums, hospital, clinics and other public facilities. Public facilities are important, because they provide both desirable services to and impose undesirable impacts on those who use the city, and from the market perspective, land to be developable must have access to a network of facilities (Yi, 2004). It is generally felt that the closer the facilities (desirable facilities) are to the users, the better the services are provided. 


\section{Standard of School Facility Planning}

The planning standards are fixed for a particular locality by studying the functional requirement, number of users, open spaces required for the building, social and climatic condition, economic activities of the locality. It is very difficult to lay down any specific standard of schools facilities in an area. It depends upon many factors such as, density of population, number of school going children per family within the study areas, road network etc. Educational facilities include preschool and formal school services. In general, the neighborhood components will include a child care center, nursery schools, and kindergartens in pre-school group, and elementary schools in the later group. These facilities must be within safe walking distance. Ideally, the children should have walking access without having to cross any vehicular streets. The maximum distance should not exceed $1 / 2$ mile. Low density areas require modification of these standards- usually met by the use of bus transportation (Chiara, 1999).

According to Private Residential Land Development Rules, 2004, space standard for education facilities in acres by population size are given in Table 1 . The standards shown in Table 1 are followed in Bangladesh in private residential land development project.

Table 1: Land Requirements for various education facilities

\begin{tabular}{|l|c|c|c|c|}
\hline \multirow{2}{*}{ Type } & \multicolumn{3}{|c|}{ Recommended space standard(in acres)for Size of population } \\
\cline { 2 - 5 } & 2500 & 5000 & 10000 & 15000 \\
\hline Nursery & .2 & .4 & .8 & 1.2 \\
\hline Primary school & .3 & .6 & 1.0 & 1.2 \\
\hline Secondary school & - & - & 1.2 & 1.5 \\
\hline College & - & - & - & 1.2 \\
\hline
\end{tabular}

Source: GOB, 2004.

A comparative scenario of standard school facility followed in Dhaka and Kuala Lumpur structure plans are presented in Table 2.

Table 2: Comparative scenario of primary and secondary school facility of Dhaka and Kuala Lumpur

\begin{tabular}{|c|c|c|c|c|c|c|c|c|}
\hline \multirow{3}{*}{$\begin{array}{c}\text { Name of } \\
\text { Metropolitan } \\
\text { Area }\end{array}$} & \multicolumn{4}{|c|}{ Facility/Unit } & \multicolumn{4}{c|}{ Facility/10000 Population } \\
\cline { 2 - 9 } & \multicolumn{2}{|c|}{ Primary school } & \multicolumn{2}{|c|}{ Secondary School } & \multicolumn{2}{|c|}{ Primary school } & \multicolumn{2}{c|}{ Secondary School } \\
\cline { 2 - 9 } & $\begin{array}{c}\text { Pop. / } \\
\text { Unit }\end{array}$ & $\begin{array}{c}\text { Area/ } \\
\text { Unit }\end{array}$ & $\begin{array}{c}\text { Pop. / } \\
\text { Unit }\end{array}$ & $\begin{array}{c}\text { Area/ } \\
\text { Unit }\end{array}$ & Unit & $\begin{array}{c}\text { Area } \\
\text { (Acre) }\end{array}$ & Unit & $\begin{array}{c}\text { Area } \\
\text { (Acre) }\end{array}$ \\
\hline Dhaka & 15000 & 1 acre & 23000 & 2 acre & .67 & .67 & .43 & .87 \\
\hline Kuala Lumpur & 10000 & 2.97 & 20000 & 4.94 & 1.00 & 2.97 & .50 & 2.47 \\
\hline
\end{tabular}

Source: DMDP, 1995; www.dbkl.gov

\section{Plan Making Process of Schools}

The conventional method in school planning involves first a determination of the number of facilities (no. of schools) needed, which is estimated based on the percentage of school-age population to the total population forecasted (equitation 1 and 2). According to the population growth rate in recent years, the forecast is performed using the following equations (modified by author from Hamid, 2002:): 
$N_{h}=\frac{P_{t} \times S_{(11-15)}}{Q_{h}} \ldots \ldots . .(1)$ and $\quad N_{p}=\frac{P_{t} \times S_{(5-10)}}{Q_{p}} \ldots \ldots \ldots . . .$.

Here, $N_{h=}$ Number of high schools are required,

$S_{(11-15)}=$ Percentage of $11-15$ years age group of total population,

$Q_{h}=$ Standard number of students for a high school.,

$N_{p}=$ Number of primary schools are required,

$S_{(5-10)}=$ Percentage of 5-10 years group of total population,

$Q_{p}=$ Standard number of students for a primary school, and

$P_{t}=$ Present total population

Finally, the total space needed for each facility is calculated by multiplying the total number of pupils by the space per pupil requires. Space requirements are assigned to the appropriate planning districts in which each such facility is located. As in the space analyses stage, a frequently applied planning technique is the drawing of a circle around public facilities, with a fixed radius-reflecting norm of a policy standard. Observing the result of theoretical service area, a distinction could be made between areas, which are properly served (serviced area), and those are not (unserviced area).

Public facilities planning normally applied planning standards. In dealing with the standard for the location of schools, the easy walking distance from residence to school is defined in distance standard, usually in terms of meters of travel.

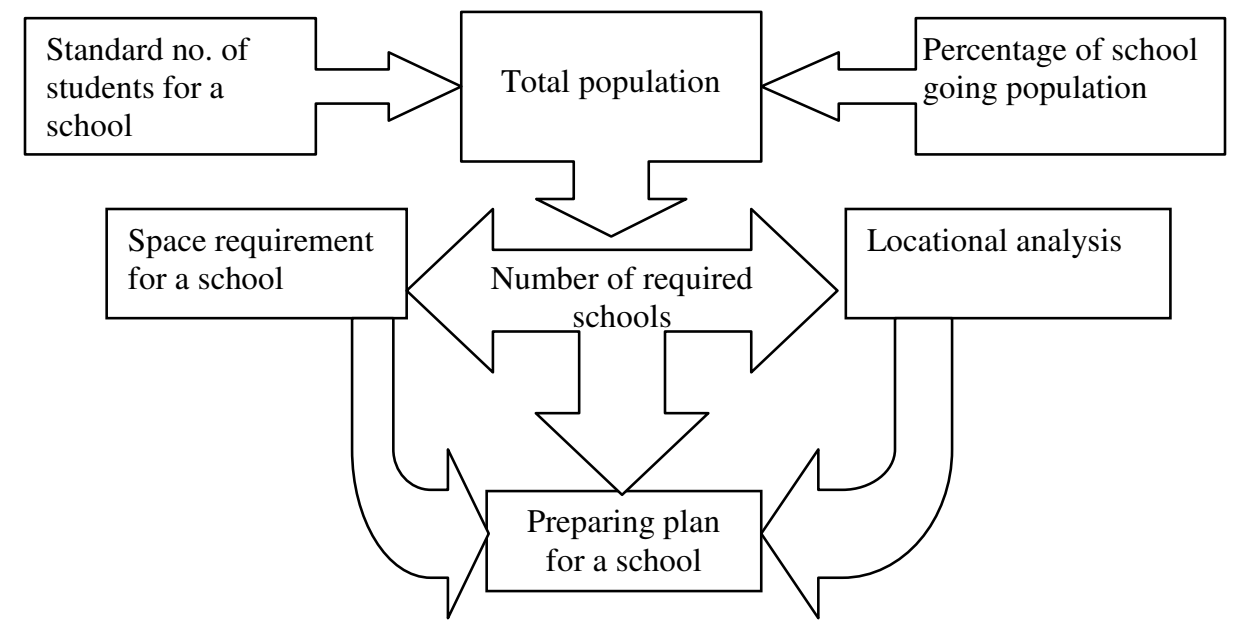

Source: Modified by author from Yi, 2004.

Fig. 1: Plan making process of a school

\section{Study Area}

Ward number 50 of Dhaka City Corporation is included in Zone-5 and SPZ-2 of DMDP area. Panthapath, Sonargaon road and Green road surround the area in the north, east and west respectively. This is mainly an unplanned and congested area of north CBD of Dhaka Metropolitan area (DMDP, 1995). 
Size of the area is $0.75 \mathrm{sq} . \mathrm{km}$ or 163 acre (BBS, 2001). Residential area covers $65 \%$ of total land, and $7.5 \%$ land belongs to commercial use, specially the plot beside Panthapath, Green road, and Sonargaon road. Vacant place cover 1.5\%, where institutional and administrative land use is $1.5 \%$ and $1 \%$ respectively. Mixed land use of the study area is $6.5 \%$. The industrial land use and road network occupy $2 \%$ and $15 \%$ respectively (Field Survey, 2007). Figure 2(a) represents the land use map of the study area and Figure 2(b) shows the population distribution in the area.

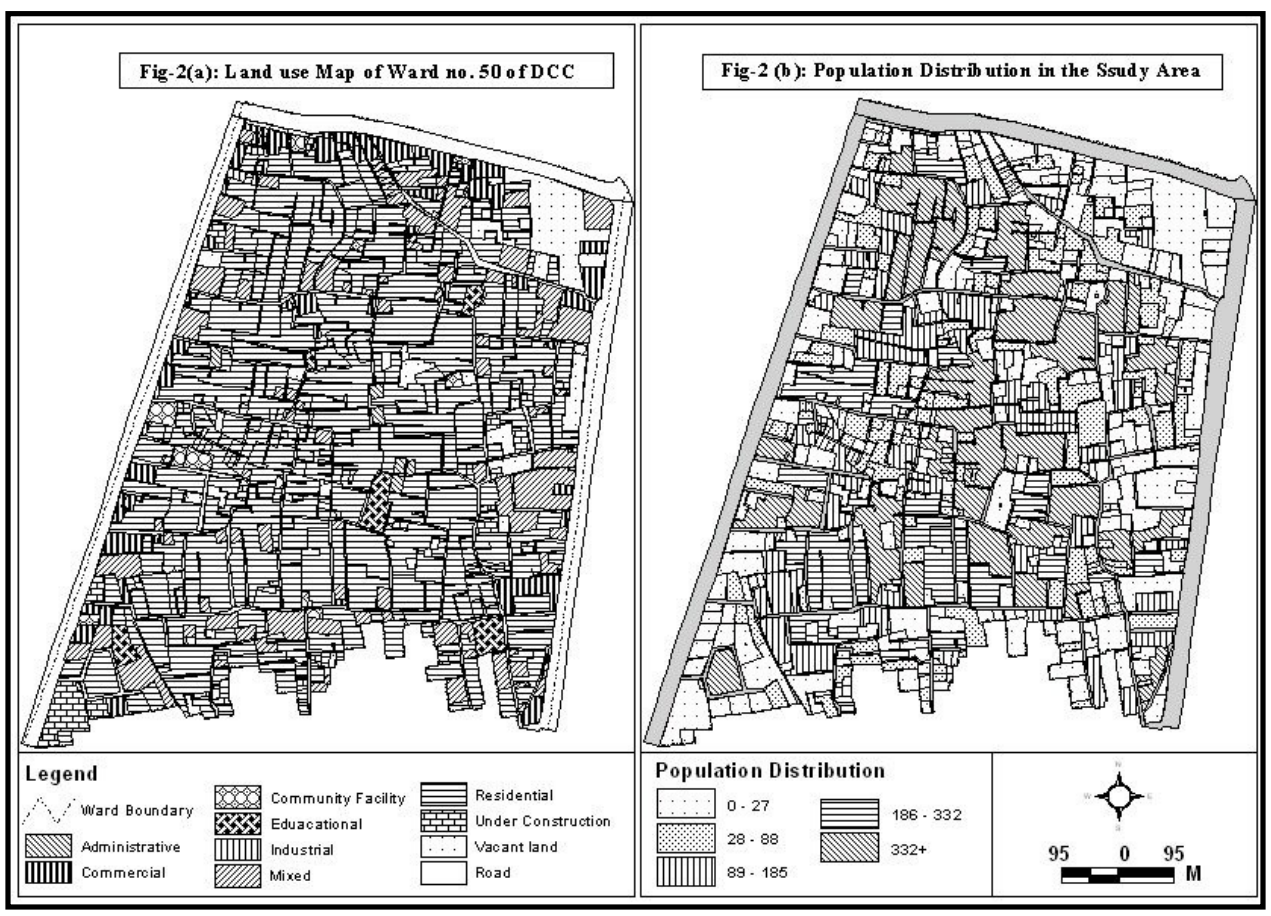

Source: Field survey, 2007.

The number of population in the study area is 67193 with 38898 male and 28295 female (BBS, 2001). Total number of household is 12411 . Over all literacy rate is $74.22 \%$ with $79.05 \%$ for male and $67.41 \%$ for female (BBS, 2001). Population density of this area is 412.22 persons per acre (BBS, 2001), while density of population in the residential area is 550 persons per acre (Field survey, 2007). Average household size of the study area is 5.41 (BBS, 2001) and residential unit of each plot is 3.37 (Field survey, 2007).

\section{School-Going Students}

Potential number of school going children within (5-9) age group are 5763, among them 1401 male and 2225 female are attending to the school. But the rest of 1074 male and 1063 female of (5 - 9) years age group are not attending to the school. On the other hand, potential number of school going children within (10-14) year age group are 7120; among them 1838 male and 1775 female attending to the school. But the rest of 1459 male and 2048 female of $(11-14)$ year age group children are not attending to the school (BBS, 2001). Number of primary school going children of each family is 0.46 and this ratio for high school going children is 0.28 . On an average, 53.65 school going students live in an acre with 33.25 primary school going students and 20.39 high school going students in ward no. 50 of Dhaka City Corporation (Field survey, 2007). 


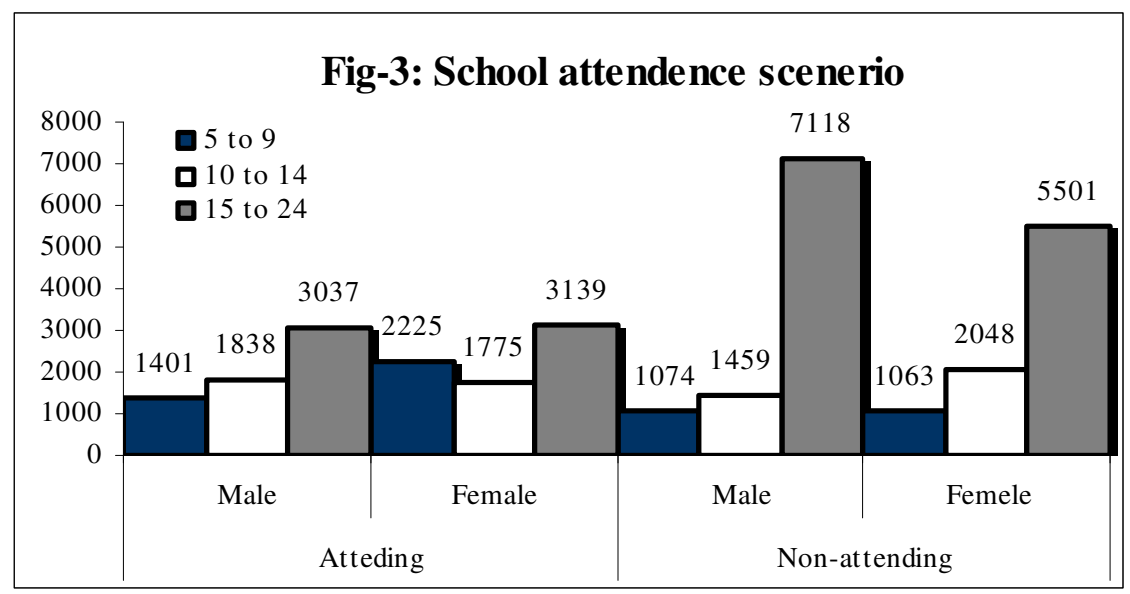

Source: BBS, 2001.

Again, 55.74\% students of total school going children are studying in educational institutions within the study area and the rest $44.25 \%$ students are studying in educational institutions outside of study area (Field survey, 2007). Figure 3 shows the scenario of school attendance by children.

\section{Use of Transport Mode by Students}

Table 3 presents the transport scenario of the students, their transport mode, per day transport cost, travel distance and travel time to go to school. It represents highest number $56.90 \%$ students prefer to walk to go to their school, $54.6 \%$ students have no transport cost to go to school, $40.23 \%$ student live within $1 / 2 \mathrm{Km}$ of the school and $54.2 \%$ students reached school within 15 minutes.

Table 3: Percentage distribution of school going children by transport mode, transport cost, travel distance and time

\begin{tabular}{|l|c|c|c|c|c|c|c|c|c|c|c|}
\hline \multicolumn{4}{|c|}{ Transport Mode } & \multicolumn{3}{c|}{$\begin{array}{c}\text { Transport Cost } \\
\text { (in Taka/Day) }\end{array}$} & \multicolumn{3}{c|}{$\begin{array}{c}\text { Travel Distance } \\
\text { (in Km) }\end{array}$} & \multicolumn{3}{c|}{$\begin{array}{c}\text { Transport Time } \\
\text { (in Minutes) }\end{array}$} \\
\hline \multicolumn{1}{|c|}{ Type } & No. & $\%$ & Type & No. & $\%$ & Type & No. & $\%$ & Type & No. & $\%$ \\
\hline Walking & 99 & 56.90 & Nil & 95 & 54.60 & Up to $1 / 2$ & 70 & 40.23 & Up to 15 & 94 & 54.02 \\
\hline Rickshaw & 37 & 21.26 & Up to 10 & 42 & 24.14 & $1 / 2-1$ & 42 & 24.14 & $16-30$ & 66 & 37.93 \\
\hline School vehicle & 22 & 12.64 & $11-20$ & 25 & 14.37 & $1-3$ & 45 & 25.86 & $31-45$ & 12 & 6.90 \\
\hline Bus & 13 & 7.47 & $21-30$ & 12 & 6.90 & $3-5$ & 4 & 2.30 & $46+$ & 2 & 1.15 \\
\hline Other & 3 & 1.72 & - & & - & $5+$ & 13 & 7.47 & - & - & - \\
\hline \multicolumn{1}{|c|}{ Total } & 174 & 100 & Total & 174 & 100 & Total & 174 & 100 & Total & 174 & 100 \\
\hline
\end{tabular}

Source: Field survey, 2007.

\section{Factors Affecting Choice of Schools}

There are a number of factors, which influence one to choose a school. In this study, 17 factors are used to know the preference of choosing a school. Based on this study, nearness to the residence is the most influential factor to choose a school. $39.31 \%$ respondedents prefer to choose school near to their residence, while $29.31 \%$ respondents prefer to choose a school due to its performance in academic results. Table 4 represents the factors to choose a school, and the number and percentage of the respondents' response to each of the factor. 
Table 4: Percentage Distribution of Students based on Factors to choice a school

\begin{tabular}{|l|l|l|l|l|l|}
\hline Criteria to choice school & No. & $\begin{array}{c}\text { Percentage } \\
(\%)\end{array}$ & \multicolumn{1}{|c|}{ Criteria to choice school } & No. & Percentage (\%) \\
\hline Reputation & 42 & 24.14 & Private school & 9 & 4.02 \\
\hline Academic results & 51 & 29.31 & Less tuition fee & 27 & 27.01 \\
\hline Faculty member & 20 & 11.49 & Your student can pass easily & 3 & 2.30 \\
\hline Near to the residence & 69 & 39.66 & Co-education & 11 & 6.32 \\
\hline Good transport system & 27 & 15.52 & $\begin{array}{l}\text { Unable to get admission } \\
\text { preferred school }\end{array}$ & 15 & 8.62 \\
\hline Special course & 3 & 1.72 & To get free studentship & 9 & 5.17 \\
\hline Good education & 42 & 18.97 & Easy to get admission & 34 & 19.54 \\
\hline Good environment & 51 & 12.07 & Other & 21 & 12.07 \\
\hline Public school & 20 & 24.71 & & & \\
\hline
\end{tabular}

Source: Field survey, 2007.

\section{Problems of Getting Admission into Schools}

About 55\% of the respondents stated that they faced different types of problems to get their children admitted into schools. The major problems related to admission of children to desired schools are: limited number of seats in the desired school (72\%); no good quality school available near to the residence; donation system, lack of information or other reasons. Here other includes high admission fee; corrupt practices etc. (Figure 4).

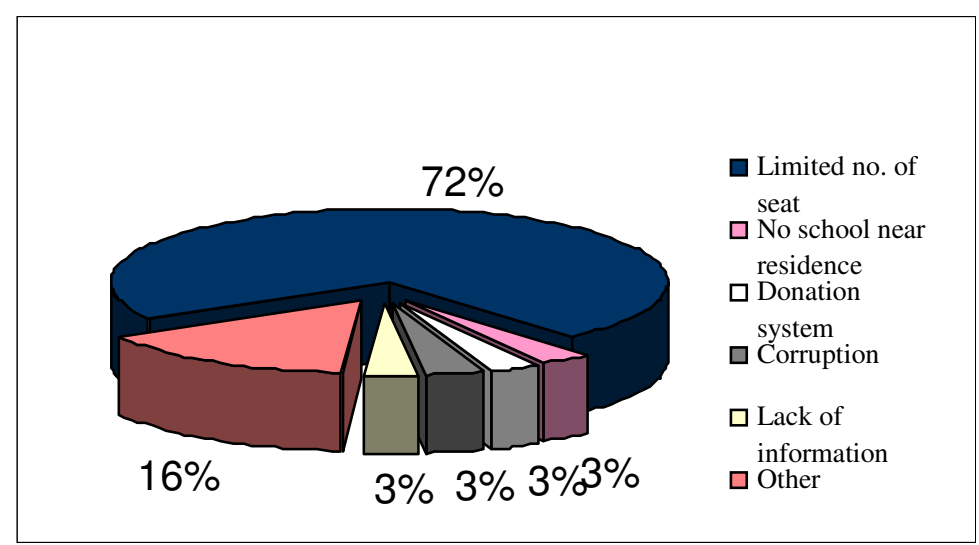

Source: Field survey, 2007.

Fig 4: Pattern of problems to get admission into school.

\section{Justification of the Location for Schools}

$70 \%$ households are pleased with existing location of the schools. But $30 \%$ households are not happy with the existing location of schools. Location justification positively response are divided five major criteria and location justification negatively response are divided seven major criteria. Justification of location by different households represents in Table 5. 
Table 5: Percentage distribution of household based on locational justification

\begin{tabular}{|l|l|c|l|c|c|}
\hline \multicolumn{2}{|l|}{ Prefer exiting location of school $(70 \%)$} & \multicolumn{3}{c|}{ Do not prefer the existing location of school (30\%) } \\
\hline Criteria & No. & Percentage $(\%)$ & Criteria & No. & Percentage (\%) \\
\hline Near to residence & 70 & 37.84 & Far from the residence & 28 & 41.79 \\
\hline Good transport network & 31 & 16.76 & Bad communication system & 6 & 8.96 \\
\hline Good environment & 26 & 14.05 & Bad environment & 4 & 5.97 \\
\hline Potentil no. of students & 48 & 25.95 & No such potential no. of student & 13 & 19.40 \\
\hline Other & 10 & 5.41 & Commercial area & 3 & 4.48 \\
\hline & & & Noise pollution & 3 & 4.48 \\
\cline { 4 - 7 } & & & Other & 10 & 14.93 \\
\hline Total & 185 & 100 & Total & 67 & 100 \\
\hline
\end{tabular}

Source: Field survey, 2007.

\section{Schools within the Study Area}

A total of seven schools are located within the study area, of which 2 are higher secondary girls' school; 1 high school; 1 junior high school and the rest of three are primary schools. A total of 3730 students are studying in these schools against 5370 seats. The highest number of students (1483) study in YWCF Higher Secondary Girls School. Table 6 represents name, year of establishment, address, type, number of students and teacher of each school in the study area. The locations of these schools are shown in Figure 2.

Table 6: Schools within the study area

\begin{tabular}{|c|c|c|c|c|c|}
\hline \multirow{2}{*}{$\begin{array}{c}\text { Name of the school and year of } \\
\text { establishment }\end{array}$} & \multirow[t]{2}{*}{ Address of the school } & \multirow[t]{2}{*}{ Type of school } & \multicolumn{2}{|c|}{ No. of students } & \multirow{2}{*}{$\begin{array}{l}\text { No. of } \\
\text { teacher }\end{array}$} \\
\hline & & & Capacity & Existing & \\
\hline $\begin{array}{l}\text { Meherunnesa Girl's School and } \\
\text { College, } 1964\end{array}$ & $\begin{array}{l}\text { 54/1 North Circular Road, } \\
\text { Dhanmomdi, Dhaka. }\end{array}$ & $\begin{array}{l}\text { Higher secondary } \\
\text { school }\end{array}$ & 850 & 305 & 42 \\
\hline Sultan Sofa Pathshala, 1980 & $\begin{array}{l}299 \text { Free school street } \\
\text { road,,Dhanmondi, Dhaka. }\end{array}$ & Junior high school & 270 & 230 & 9 \\
\hline $\begin{array}{l}\text { YWCA Higher Secondary Girls } \\
\text { School, } 1976\end{array}$ & $\begin{array}{l}\text { 10/11 Green Square, Green } \\
\text { Road, Dhanmomdi. }\end{array}$ & $\begin{array}{l}\text { Higher secondary } \\
\text { school }\end{array}$ & 1620 & 1483 & 50 \\
\hline Dhanmondi high School, 1964 & $\begin{array}{l}14 \text { Free school street, Hatirpul, } \\
\text { Dhanmondi }\end{array}$ & High school & 1200 & 607 & 21 \\
\hline $\begin{array}{l}\text { Dhanmondi Govt. Primary } \\
\text { School, } 1950\end{array}$ & $\begin{array}{l}14 \text { Free school street, Hatirpul, } \\
\text { Dhanmondi }\end{array}$ & Primary school & 480 & 375 & 13 \\
\hline $\begin{array}{l}\text { Khan Hasan Ideal Govt. } \\
\text { Primary School, } 1966\end{array}$ & $\begin{array}{l}\text { 18, Free school street, } \\
\text { Kathalbagan, Dhaka. }\end{array}$ & Primary school & 720 & 511 & 21 \\
\hline Rodin Kinder Garden, 1990 & 40, Free school street, Dhaka. & Primary school & 230 & 219 & 9 \\
\hline \multicolumn{3}{|c|}{ Total } & 5370 & 3730 & 165 \\
\hline
\end{tabular}

Source: Field survey, 2007.

Again, Table 7 represents name, total area, built up area, number of class room and total floor space of each school in the study area. 
Table 7: Total area, built up area, number of class rooms and floor space of schools of the study area

\begin{tabular}{|c|c|c|c|c|c|}
\hline \multirow{2}{*}{ Name of the school } & \multicolumn{3}{|c|}{ Area within the school in acre } & \multirow{2}{*}{$\begin{array}{l}\text { No. of class } \\
\text { room }\end{array}$} & \multirow{2}{*}{$\begin{array}{l}\text { Total Floor } \\
\text { Space (sq ft) }\end{array}$} \\
\hline & Total area & Build up & Vacant & & \\
\hline Meherunnesa Girl's School and College & 0.83 & .40 & .43 & 30 & 16440 \\
\hline Sultan Sofa Pathshala (rented) & 0.21 & 0.21 & Nil & 4 & 576 \\
\hline YWCA Higher Secondary Girls School & 0.74 & .55 & .19 & 40 & 820000 \\
\hline Dhanmondi High School & 0.53 & .45 & .08 & 12 & 16500 \\
\hline Dhanmondi Govt. Primary School & 0.19 & .15 & .05 & 8 & 12500 \\
\hline Khan Hasan Ideal Govt. Primary School & 0.30 & .22 & .08 & 18 & 255000 \\
\hline Rodin Kinder Garden & 0.07 & .07 & Nil & 4 & 2000 \\
\hline
\end{tabular}

Source: Field survey, 2007.

\section{Requirements of Schools}

To identify the total number of schools required within the study area, Dhaka Metropolitan Development Plan (DMDP, 1995) was followed. Depending on this planning standard, requirement of schools within the study area is justified in two ways, first the number of schools with respect to the population size and second, the total area required for the entire population are determined.

Requirements of Schools in Terms of Population: Considering the standard of DMDP, family size and per family school going students in ideal situation, threshold students of a primary school is 595.Considering the present density and land use pattern, the threshold number of students stands at 650 for a primary school in the DMD area. But, only $56.89 \%$ of primary school going students study within the study area and this also reflect determination number of school within study area. Again considering these same factors in ideal situation threshold students of a high school is 1190.Table 8 describe the scenario of requirement of school in ideal situation and present trend of DMD area and also represents addition need of school to meet the demand of the locality.

Table 8: Requirement of school within the study area ${ }^{1}$

\begin{tabular}{|l|c|c|c|c|c|c|}
\hline \multirow{2}{*}{ Type of school } & \multicolumn{3}{|c|}{ Ideal situation } & \multicolumn{3}{c|}{ Present Trend in DMD area } \\
\cline { 2 - 7 } & Pr. & Req. & Add. need & Pr. & Req. & Add. Need \\
\hline Primary school & 5 & 9 & 4 & 5 & 8 & 3 \\
\hline High school & 3 & $2(\mathrm{HS}), 1(\mathrm{H}) 1(\mathrm{JH})$ & Nile & - & - & - \\
\hline
\end{tabular}

Source: DMDP, 1995 and DCC 2003.

Requirements of Lands for Schools: Depending on DMDP standards, the case study area will require 4.48 acres of land for primary schools. In case of high school, this requirement is 5.84. Table 9 presents the standard for primary and high schools in study area.

1 In Table-6.11,Pr, Req. and Add. Need represented as present number of school within study area; requirements of school in terms of DMDP-1995 standard, and additional needs to establish school within the study area. Again, HS, H and JH represented as respectively higher secondary school; high school and junior high school. 
Table 9: Land requirement for schools within the study area

\begin{tabular}{|l|l|c|c|c|}
\hline \multirow{2}{*}{ Type of Schools } & \multicolumn{2}{|c|}{ Standard (DMDP, 1995) } & \multicolumn{2}{c|}{ Area for School in Study Area } \\
\cline { 2 - 5 } & \multicolumn{1}{|c|}{ Standard } & Required area & Existing & Additional need \\
\hline Primary school & 1 acre per 15000 population & 4.45 (acre) & .92 (acre) & 3.53 (acre) \\
\hline High school & 2 acre per 2300 population & 5.84 (acre) & 1.95 (acre) & 3.89 (acre) \\
\hline
\end{tabular}

Source: DMDP, 1995 and DCC, 2003.

\section{Conclusion}

In terms of DMDP standard, 4 additional primary schools are needed in the Study Area, Ward 50. But if we take into consideration the present trends of school facilities in Dhaka metropolitan area, 3 primary schools are required. At present, only 56.89\% school going children get admission into schools within the study area, which indicates that there is no need for additional primary schools in the study area. In terms of units, there is no need for additional high schools in the study area. But a glooming picture is observed in the quantity of land used for each school while compared with standard land required for each school. In case of primary and secondary schools, 3.53 and 3.84 acres of land are required respectively. Another depressed scenario is that $72 \%$ respondents (who face problem to get admission of their children in school) claimed that the limited number of seats is the main obstacle to get their children admitted into the schools, but in reality, it was found that 1640 seats of primary and secondary schools were remaining vacant in the study area.

The findings of the research reveal that if all the school going children would have attended the schools, some more schools would have been required. The methods applied in this research for choosing the locations of schools, could be useful in locating the additional schools appropriately. It is expected that this research has illuminated some thoughts in this respect.

Finally, Bangladesh is a country of resource scarcity. Here available facilities for standard living in cities and towns are inadequate. The conditions of public facilities are also the same in the country. The scenario is more miserable in case of Dhaka metropolitan area. This paper has explored that there is inadequate provision of land for educational institutions in Dhaka city. These institutions in reality have failed to get threshold students due to poor quality of education and locational disadvantages of these institutions. It should, therefore, be our prime concern to provide adequate space for each facility and at the same time, ensure its optimum utilization.

\section{References}

American Society of Civil Engineers (ASCE), 1986. Urban Planning guide, New York: American Society of Civil Engineers.

BBS, 2004. Statistical Year book, Dhaka: Bangladesh Bureau of statistics, Government of Bangladesh.

Chiara, J. De. 1999. Time-Saver Standards for Residential Development. New York: McGraw-Hill.

DDKL.2007. http://www.dbkl.gov.my/pskl2020/english/faq.htm, retrieved on 22 January 2009

DMDP, 1995. Dhaka Metropolitan Development Plan, Vol-II. Dhaka: Rajdhani Unnayan Kartripakkha.

GoB. 2004. Private Residential land development Rules, 2004, Dhaka: Government of Bangladesh.

Hamid, A. 2002. Planning a Neighbourhood, Dhaka: Hamid Foundation.

Massam, B. H. 1993. The right place: shared responsibility and the location of public facilities, London: Longman.

Murtaza, M. G. 2009. Working Paper, Recommended Physical Standards in Preparing Master Plan for the Upazila Towns/Pourashavas, Upazila Towns Infrastructure Development Project, Government of the People's republic of Bangladesh, Dhaka: Local Government Engineering Department.

Yi, L. 2004. Evaluation of Accessibility to Primary Schools, The case of Yuhua, Changsha, China, Msc Thesis, Department of Urban Planning and Land Administration, International Institute for Geoinformation Science and Earth Observation Enschede, The Netherlands.

BBS, 2001. Dhaka District Cencus. Published in March 2007. Dhaka: Bangladesh Bureau of Statistics, Government of Bangladesh. 